\title{
Consciousness-raising tasks for the mediation of text structure, cohesion, and coherence in essay writing
}

Actividades de concientización para la mediación de estructura de texto, cohesión, y coherencia en la escritura de ensayos

\section{Volumen 20, Número 2 \\ Mayo - Agosto \\ pp. 1-27}

\author{
Ana Lucía Rojas Vargas \\ Ana Paula Solano Quesada \\ José Miguel Vargas Vásquez \\ Alex Jiménez Rojas
}

\section{Citar este documento según modelo APA}

Rojas Vargas, Ana Lucía., Solano Quesada, Ana Paula., Vargas Vásquez, José Miguel. y Jiménez Rojas, Alex. (2020). Consciousness-raising tasks for the mediation of text structure, cohesion, and coherence in essay writing. Revista Actualidades Investigativas en Educación, 20(2), 1-27. Doi. 10.15517/aie.v20i2.41669 


\title{
Consciousness-raising tasks for the mediation of text structure, cohesion, and coherence in essay writing
}

Actividades de concientización para la mediación de estructura de texto, cohesión, y coherencia en la escritura de ensayos

\author{
Ana Lucía Rojas Vargas ${ }^{1}$ \\ Ana Paula Solano Quesada² \\ José Miguel Vargas Vásquez 3 \\ Alex Jiménez Rojas ${ }^{4}$
}

\begin{abstract}
Several studies have demonstrated the positive impact of Consciousness-Raising tasks (CRTs) on the teaching of grammar, especially in foreign or second language learning. However, few studies have examined their effectiveness for the development of writing skills. With this in mind, the goal of this project is to explore the impact of CRTs on three aspects of writing in expository essays: text structure, cohesion, and coherence. To accomplish this goal, the study followed a mixed-method approach with a component of Classroom Action Research. The study was conducted in an English as Foreign Language class with a group of 12 eleventh-grade students at the International Baccalaureate Program at Palmares Bilingual High school, in Alajuela, Costa Rica. The data consisted of two sets of essays, classroom observations, and questionnaires to the students and the cooperating teacher. After comparing results from the first and second essays, the most noticeable improvement in the students' writing was in text structure and cohesion, whereas coherence showed the lowest improvement. This points to a limitation of CRTs for addressing aspects of writing involving a larger number of rules and more abstract concepts, such as coherence, instead of a smaller number of rules, like cohesion. In conclusion, the authors suggest enquiring about the use of CRTs with simple topics involving decisions tied to explicit rules versus more complex topics involving abstract thinking and decisions not always linked to rules. Lastly, the authors recommend exploring strategies to make consciousness-raising a collaborative process as a way to mitigate task complexity.
\end{abstract}

Key words: english, consciousness-raising, writing tasks, teaching, essays.

Resumen: Una gran cantidad de estudios han demostrado el impacto positivo de las Actividades de Concientización para la enseñanza de la gramática, especialmente en el aprendizaje de lenguas extranjeras o segundas lenguas. Sin embargo, pocos estudios han examinado su efectividad para el desarrollo de las habilidades de escritura. De ahí que, el objetivo de este artículo fue explorar el impacto de estas actividades en tres aspectos de escritura de ensayos expositivos: estructura del texto, cohesión, y coherencia de acuerdo con los resultados de un proyecto de investigación. Para lograr este objetivo, el estudio siguió un método mixto con un componente investigación acción en el aula. El estudio fue realizado en una clase de inglés como lengua extranjera con un grupo de 12 estudiantes de undécimo año en el Programa de Bachillerato Internacional en el Colegio Bilingüe de Palmares, en Alajuela, Costa Rica. Los datos consistieron en dos conjuntos de ensayos, observaciones de clase, y cuestionarios aplicados al estudiantado y al profesor colaborador. Después de comparar los resultados del primer y segundo ensayo, la mejoría más notable fue en la estructura del texto y en cohesión, mientras la coherencia mostró la mejoría más baja. Lo anterior apunta a una limitación de los CRTs (siglas en inglés) para abordar aspectos de escritura que involucran un mayor número de reglas y conceptos más abstractos, como coherencia, en lugar de un número menor de reglas, como cohesión. En conclusión, se sugiere indagar sobre el uso de los CRTs con temas simples que involucren decisiones vinculadas a reglas específicas versus temas más complejos que involucren pensamiento abstracto y decisiones no siempre vinculadas a reglas. Por último, se recomiendan explorar estrategias para hacer que la concienciación sea un proceso colaborativo como manera de mitigar la complejidad de la tarea.

Palabras clave: inglés, actividades de concientización, escritura, enseñanza, ensayos.

\footnotetext{
${ }^{1}$ Advance Academy, Palmares, Costa Rica. Dirección electrónica: analu rova@hotmail.com Orcid https://orcid.org/0000-0002-8490-2209

${ }^{2}$ Green Valley Atenas School, Atenas, Costa Rica. Dirección electrónica: psolano@gvs.ed.cr Orcid https://orcid.org/0000-0002-0451-5429

3 Universidad de Costa Rica, Sede de Occidente, Costa Rica. Docente de lengua inglesa. Dirección electrónica: jose.vargas v@ucr.ac.cr Orcid https://orcid.org/0000-0002-1260-0367

${ }^{4}$ Asesor independiente, Costa Rica. Dirección electrónica: jimenez alex23@hotmail.com Orcid https://orcid.org/0000-0001-9044-0269
}

Artículo recibido: 29 de octubre, 2019

Aprobado: 27 de abril, 2020 


\section{Introduction}

Bringing students to master writing skills in a foreign language is a desired goal of many secondary education schools. In Costa Rica, the Palmares Bilingual High School is not an exception; students are required to take reading and writing lessons beginning in their first year. More specialized writing courses are later offered to students who have enrolled in the International Baccalaureate Program (IBP) given that they are expected to apply to universities abroad and to participate in a more demanding working environment.

Essay writing is one of the most frequently addressed tasks in higher education, which is the next step for high school students due to its importance in the academic context. For instance, when teachers attempt to instruct students on how to write essays, most of them teach students what essays should contain instead of teaching them how to write formal elements. That is, instructors often focus more on the content of the essay and the development of the ideas and not as much on their structural elements and the correct use of language for achieving the intended goal. In order to help students to focus on language, a more sensible approach is needed, integrating attention to language form as a way of triggering awareness and critical thinking on the part of students, both to meticulous attention to language form and to the content presented.

The teaching of writing in the IB is considered a necessary tool for the students' growth and also a complex endeavor for them and for the instructors, partly because the syllabus is aimed at promoting the necessary skills for students to engage in real life scenarios, both academically and professionally. Having said this, students should receive proper instruction in all kinds of writing conventions.

One possible solution for students to achieve text structure, cohesion, and coherence is the implementation of Consciousness-Raising Tasks (CRTs). As defined by Rutherford and Sharwood-Smith (1985), CRTs have their core on "the drawing of learners' attention specifically to the formal properties of the target language" (p.129). Similarly, Roza (2014) mentions that CRTs "help learners acquire conscious knowledge which can be used to understand input and monitor their own output" (p.3). The difference between the input and the students' output constitutes a gap, whose conscious exploration is expected to lead to awareness and improvement. The activities proposed through CRTs can expose students to the basic essay structure, the way sentences are linked, and the harmonious flow of ideas through text examples. With more attention provided to language form through these tasks, 
students' performance in writing is expected to improve, achieving a balance in content development and attention to language form.

There are several studies conducted on CRTs in Second Language Acquisition (SLA); however, most of them are aimed at the learning of grammar in higher education in universities abroad. The study of Barrantes, Madrigal, Quesada, Salazar, and Rojas (2018) is the only study at a national level in a high school, which makes their methodology and results highly relevant for this study. The researchers of the current study consider that by mixing quantitative and qualitative strategies to collect data, they could achieve a better understanding of the different steps involved in a CR cycle. Moreover, this project aimed at assessing the effectiveness of CRTs in writing, particularly for the mediation of text structure, cohesion, and coherence, in expository essays written by eleventh graders of the International Baccalaureate in Palmares Bilingual High School in Costa Rica.

\subsection{Objectives}

The main objective of the study was to assess the effectiveness of consciousnessraising tasks for the mediation of text structure, cohesion, and coherence in expository essays written by eleventh graders of the International Baccalaureate in Palmares Bilingual High School to determine their potential applicability in the school's program.

The project also focused on the following specific objectives:

First, to apply CRTs to mediate text structure, cohesion, and coherence in expository essays through class interventions.

Second, to evaluate students', cooperating teacher's, and researchers' perception of the effectiveness of CRTs for the features in question in order to determine strengths and drawbacks of this technique by triangulating the participants' points of view.

\section{Theoretical Framework}

\subsection{The Role of Noticing in Foreign Language Acquisition}

Noticing has become a controversial issue concerned with the conscious and unconscious processes of foreign language acquisition. Cross (2002) discussed the need to consider analyzing the theoretical form of the role of noticing and the validity of the Noticing Hypothesis. The author realized that the process of language acquisition has gone through different theories, and he mentioned authors such as Ellis (1990), Schmidt (1990), and Truscott (1998) with some of their theories and their adaptations. The Noticing hypothesis 
proposed by Schmidt (1995) states that " what learners notice in input is what becomes intake for learning" (p.20). This means that L2 learners may not process input unless they notice it. In other words, the noticing hypothesis claims that when a learner notices a linguistic form, it becomes intake.

To clearly understand the noticing hypothesis, Ellis (1997) proposed a model to exemplify the process of learning implicit knowledge presented on Figure 1.

Figure 1

The process of learning implicit knowledge

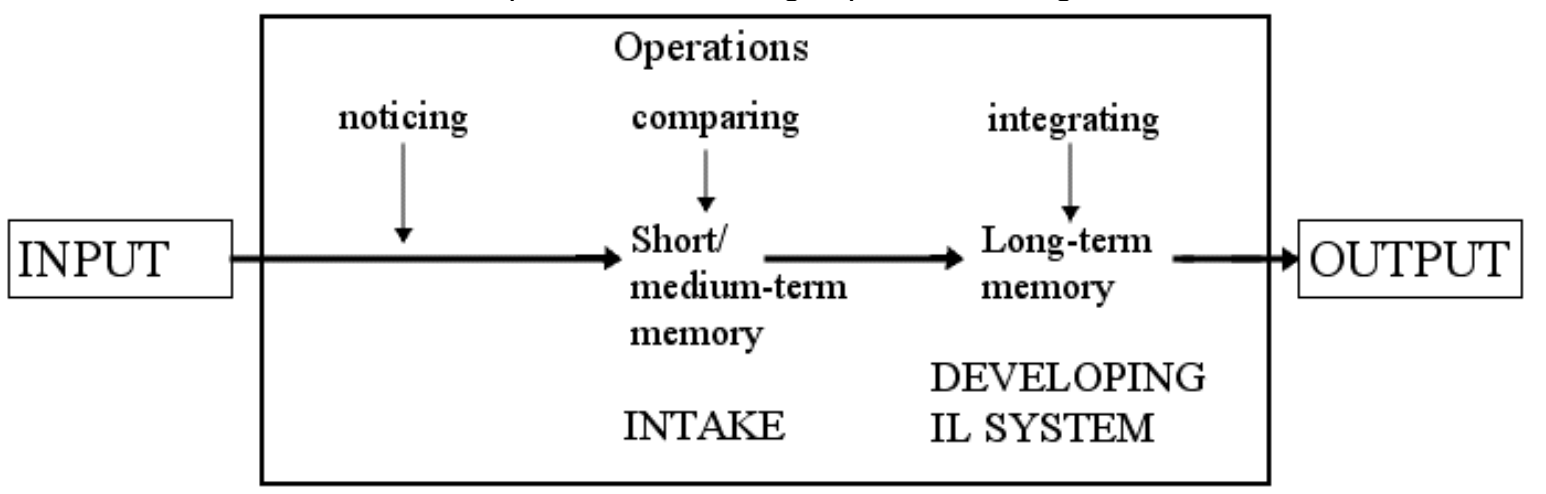

Source: Taken from SLA Research and Language Teaching by Rod Ellis (1997)

Ellis' model divides the process of learning implicit knowledge into two stages. In the first stage, the input has to be noticed to become intake in short or medium-term memory. In the second stage, the intake goes through an interlanguage system. Then, the noticed language becomes integrated into long-term memory. However, Truscott (1998) argued that the noticing hypothesis in cognitive psychology is weak and there are no studies that support the hypothesis. Additionally, Truscott stated that the noticing hypothesis has two versions: strong and weak. In the strong version, details on the grammatical form are crucial; also, noticing is seen as a fundamental part of learning. On the other hand, the weak version does not focus on details on the form, claiming that noticing is helpful but not necessary. The author also argued that discussions of noticing are against theories of unconscious acquisition; that is, theories focusing on global awareness and not on details. However, the acquisition may be a result of the input learners are aware of, including details, rather than of global awareness of input.

Although Truscott (1998) criticized the Noticing Hypothesis due to lack of theoretical and scientific support, authors such as Ellis (1994), Gass (1988), and Rutherford (1987) supported Schmidt's hypothesis that noticing a feature in the input is essential for learning. 
Ellis' model classifies noticing as the first step after input is perceived. Then, intake goes through a process to become output.

\subsection{Consciousness-Raising Tasks}

Fotos and Ellis (1991) have suggested a task-based approach (TBA) to grammar instruction using a type of task, which provides learners with grammar problems to solve interactively; they call it grammar consciousness-raising tasks (CRTs). CR is an approach to language teaching that aims to help learners become aware of what they are producing. Therefore, such tasks are designed to help learners to draw conclusions by noticing particular features of the language, such as rules and patterns, through a guided process.

According to Ellis (2002), "the purpose of CRTs is not to enable learners to perform a structure correctly, but to help them realize its existence" (p. 169). Hence, the main goal of CRTs is to make students aware of where errors occur and how they can be solved correctly. To achieve such an end, Roza (2014) stated the purposes of CR activities:

1. To direct learners' attention to grammar features they might not notice on their own.

2. To help learners make form-meaning connections.

3. To help learners acquire conscious knowledge which can be used to understand input and monitor their own output (p.3).

Therefore, the main purpose of CR, then, is to provide learners with the necessary tools to analyze and understand input on their own and, then, monitor their output.

Krashen (1982) proposed a theory in which learners monitor their input and edit the language they have produced. This theory is the Monitor Hypothesis and explains how learning is regulated. The monitor is what helps learners notice the forms and structures that they are producing and compare them with what they have already acquired.

According to Widodo (2006) there are two methods for grammar instruction, namely deductive and inductive. In the deductive method, learners know the rule explicitly. In contrast, in the inductive methods students discover the rule or the form by themselves.

In the deductive method, the basic assumption is that information goes from general to specific. All the information, rules, theories, and concepts are presented at the beginning of the lesson. Students are guided by the teacher, who provides the rules, gives examples, and concludes with the assessment to test the student's understanding. 
In the inductive method, the information goes from specific to general. According to Widodo (2006) "when we use induction, we observe a number of specific instances and from them infer a general principle or concept" (p. 127). Students are the center of the process while discovering the rules, the structures, and the theories. The teacher is only a guide who provides examples of the topic and who helps students notice the rule. At the end, the teacher explains the topic to the students.

Widodo observed that both the deductive and inductive methods have significant value for teaching grammar, with a series of advantages in each case. Students can learn deductively and inductively, depending on their cognitive style. In light of this, Widodo has proposed a procedure for teaching grammar with a combination of deductive and inductive methods. This procedure is divided into five steps and explained by the Rhetorical Cycle of Consciousness-Raising proposed by Swales and Feak (2009). This is divided into analysis, awareness, acquisition, and achievement as presented in Figure 2.

Figure 2

The Cycle of Rhetorical Consciousness-Raising

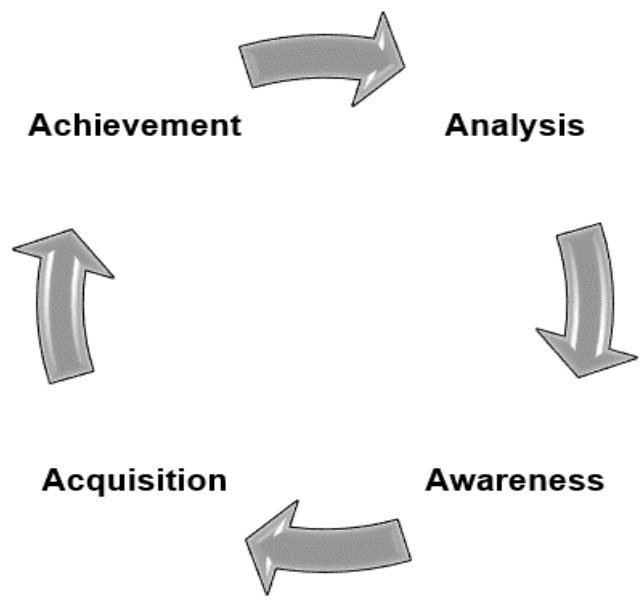

Source: From Swales and Feak (2009, p. 252)

The first step in the cycle is analysis. In this step, students are guided by the teacher, whose hints help them break up the rules and come up with the correct usage of the rules on their own. This step of the cycle is similar to Widodo's first step, which consists of building up students' knowledge of the rule or the rule initiation. Additionally, the teacher is a guide who teaches a feature through a series of questions. This step can be presented as an analysis of the feature. Also, the teacher can provide underlined or highlighted model sentences and the questions. This can help students focus on the specific feature presented. At this stage, the 
teacher should not tell the students the features they are going to learn until the end. The reason that the teacher should not facilitate the feature to the students is to enable them to internalize the feature by themselves.

Awareness is proposed as the second stage of the cycle. According to Tomlin and Villa (1994), awareness is defined as "a particular state of mind in which an individual has undergone a specific subjective experience of some cognitive content or external stimulus" (p. 193). Awareness is related to the second step provided by Widodo (2006). The objective of this step is to bring out the functions of the feature followed by examples. In this step, students become aware of the uses of the feature and can apply the rule in different settings. Students can discover what they guessed in the previous step. In this step, the teacher provides functions, uses, and examples, and the students should be prepared for the following exercises.

The next step of the cycle is acquisition, regarded in SLA as a process of developing the ability to acquire language for communication. According to Krashen (1982), this is a subconscious process in which learners are not aware of the process of acquiring language but are only aware of the fact that they are using the language to communicate. Although the acquisition is not a noticeable fact for students it does happen while trying to communicate. This step relates to Widodo's third and fourth steps; in the third step, learners become familiar with the feature being taught by completing exercises that enhance their understanding and encourage their active involvement. For example, the activities mentioned by Widodo (2006) are the completion of sentences by using the correct tense form or time signal, error recognition and correction, and sentence composition. Then, the fourth step is checking students' comprehension or rule activation. In this step, the teacher has to test students' understanding of the feature taught. Students have to write sentences using the rule learned. The difference between step 3 and step 4 is that in the third step learners practice the rule and become familiar with it in guided exercises while in the fourth step students apply the rule in free practice by writing sentences.

Finally, Swales and Feak (2009) define achievement as a final stage in the four-part process. The aim here is to culminate in learners' own production by recognizing and appropriately using the feature or rule under study. Similarly, in Widodo's study, the last step focuses on expanding learners' understanding of the feature. To reinforce previous or new concepts or rules, pattern identification in a text and inter-pattern comparison in meaning might be used as examples. Pattern identification encourages learners to engage in CR by 
identifying the rules in a given text. Then, inter-pattern comparison in meaning leads learners to differentiate between the concepts they already know and the newly introduced item.

\subsection{Principles for mediating text structure, cohesion, and coherence}

\subsubsection{Text Structure}

A piece of writing must follow a standard pattern to be considered an essay. The typical pattern of an essay according to Zemach and Rumisek (2003), and Perutz (2010) consists of an introduction, the main body, and a conclusion.

Perutz (2010) referred to the introduction as the first paragraph of an essay that explains the topic with general ideas. This first paragraph has a series of elements, for instance, beginning with a hook. Hooks are sentences mainly intended to catch the reader's attention. In regard to the hook, Zemach and Stafford-Yilmaz (2008) stated that they need to be "followed by some background explaining a little bit of the topic to be discussed, leading the reader to the thesis statement" (p.28). This is what Zemach and Rumisek (2003) stated by saying that an essay's introduction should "give a brief outline of the issues to be explored within the essay and in which order they will be developed" (p.4). Put it differently, after catching the reader's attention, the writer lets the reader know what the essay will be about and also the order in which the ideas will appear throughout the essay.

For writing a good thesis statement, Zemach and Stafford-Yilmaz (2008) suggested including the essay topic and the writer's opinion while being specific and clear. A thesis statement can also list the supporting ideas. Additionally, the introductory paragraph grabs the reader's attention and makes him/her aware of the information that will be discussed in later paragraphs.

Writing the body of an essay, according to Zemach and Stafford-Yilmaz (2008), is "putting down your thoughts in clear sentences that flow logically from one to another." (p.79). Thus, writers should look for the best way to put thoughts into words while using good transitions that make the reader smoothly go from one idea to the other without breaks. Each body paragraph should contain other sentences to develop the topic and to include relevant examples, details, evidence, quotations, and references. Additionally, each of these paragraphs needs to be connected to the previous one with the use of sentences or transition words that link paragraphs.

For Zemach and Rumisek (2003), the conclusion is the last paragraph of an essay. It summarizes or restates the thesis and the supporting ideas of the essay. For Perutz (2010), 
"a conclusion serves the purpose of summarizing the themes, stating general conclusions and why they are important" (p.5). The latter author added that the conclusion should never introduce new material or topics. Also, a conclusion should contain a closing device in addition to the previously mentioned elements.

\subsubsection{Cohesion}

In academic essays, fostering cohesion structurally might be necessary to direct and enhance the readers' attention to the development of arguments. Crossley and McNamara (2010) defined cohesion as "the presence or absence of explicit cues in the text that allows the reader to make connections between the ideas in the text" (p.984). In other words, cohesion creates unity in a piece of writing by making links among sentences and paragraphs.

As a matter of fact, Cox, Shanahan, and Sulzby (1990) mentioned that different cohesive devices, or types of cohesive ties, help the reader to construct meaning, and the writer in creating a comprehensible text. Ferris (2014) suggested different techniques to achieve cohesion in a piece of writing. One suggested way is to make word choice cohesive by repeating words, using synonyms, pronouns, and determiners. However, the writer should avoid overusing repetition of words, and unclear or unknown lexicon. Another suggestion is to create a cohesive sentence structure by keeping subject and verb together. The same author also suggested placing old information near the beginning of the sentence and providing the reader with a clear connection to other sentences in the paragraph.

Nugraheni (2016) suggested that using transitions between sentences or phrases can help the text to achieve the appropriate flow in its sentences. The writer selects the best transition depending on their function (addition, contrast, cause-effect, etc.). As for the transition words (also called connecting words), they are words that show the relationship between ideas. They connect one sentence to another, as well as one paragraph to the next. There are different types of connecting words. These transition words are meant to connect sentences or clauses and to show the relationship of ideas; however, the punctuation rules may vary for each of the transition words.

\subsubsection{Coherence}

All texts, essays, articles, or any other piece of writing must be coherent. To express an idea, thought, claim, or a problem, their meaning should be clear, and they have to be 
connected to the following idea. According to Driscoll and Brizee (2015), coherence is "the trait that makes the paragraph easily understandable to a reader" (para. 5). For example, editing for coherence means to fit all the ideas in a logical order, making a clear relation between words, sentences, and paragraphs; this may help the text to achieve an appropriate flow. In this sense, the semantic relation establishes the alliance between words and phrases based on the meaning of words, this relation should make the text easy to read.

Coherence can be achieved in several ways. Ferris (2014) established that in order to achieve coherence in a text, the writer must focus on its purpose. Students can achieve an appropriate connection of ideas by brainstorming or creating an outline. This can help to order the sentences in each paragraph and create a continuous flow with the other paragraphs. Furthermore, Ferris also argued that after ideas and the purpose of the text are clear, this purpose must be reflected in the thesis statement. The thesis "clearly explains what the text is about" (p. 75). In the end, she concluded that to evaluate coherence in a text, a writer should identify a topic sentence that supports the main idea of the paragraph. Also, each paragraph should have an explicit connection to the thesis statement of the essay, and the phrases in the paragraphs should be connected to the ideas of the previous or following paragraphs. Lastly, for the purpose of this study, it is important to distinguish that whereas cohesion is aimed at the connection between sentences in a text, coherence will be measured according to the thematic relationship between the different sections in a text.

\section{Methodology}

\subsection{Design}

This study followed a mixed-method approach, focused primarily on qualitative data due to the relatively small number of participating students, but with a quantitative component consisting of a brief descriptive statistical analysis, albeit without the aim of identifying significant differences between the pre- and the post-test. This allowed the researchers to achieve a stronger understanding of the problem than by using either method by itself (Creswell, 2014). The purpose of relying on this type of design was to embed quantitative and qualitative information through a series of instruments: written assignments, rubrics, observation forms, questionnaires, and an interview. The quantitative analysis focused on the results obtained in the pre-test, post-test, and the tasks applied to students in the teaching of text structure, cohesion, and coherence in essay writing. The qualitative analysis consisted of a triangulation of information retrieved from observations and interviews. 
The project was also carried out taking into account methodological aspects from Classroom Action Research (CAR). According to Mettetal (2002), one of the aspects to improve the teaching practice in CAR is identifying what works best in the classroom to enhance it, allowing the teacher to maximize students' learning. This method is part of the qualitative research approach, having the goals of observing, documenting, analyzing, and interpreting characteristics and patterns of the population under study. In addition, CAR was an approach that allowed the researchers to reflect on the results of the tasks and make adjustments in the interventions in agreement with the feedback provided by the students and the cooperating teacher.

\subsection{Participants}

\subsubsection{Students}

The study was conducted at International Baccalaureate (IB) in Palmares Bilingual High School, located in Palmares, Alajuela, Costa Rica. The participants were a group of eleventh graders whose age ranged from approximately 17 to 18 years old, consisting of 8 females and 4 males. The students were chosen to be part of the present project because they already had previous knowledge on how to produce pieces of writing in English. Therefore, their selection was intentional.

\subsubsection{Cooperating teacher}

The IB cooperating teacher was a 38-year-old female and was in charge of monitoring the pedagogical interventions. The cooperating teacher was an internal source of data given that he/she was acquainted with his/her students' performance.

\subsubsection{Researchers}

Four researchers whose age range from 24-33 years old, carried out this project taking an active role in the research process by applying the pre-test and post-test, designing and carrying out CRTs interventions, and observing the students' development and performance during each intervention. Additionally, they were in charge of applying data collection instruments such as observation sheets and questionnaires to students and an interview to the cooperating teacher to retrieve information concerning the students', cooperating teacher's, and researchers' perception of the effectiveness of CRTs. After that, the 
researchers analyzed the data collected to provide results and possible ways of improving CRTs applied to students.

\subsection{Instruments}

\subsubsection{Pre-test}

The aim of the pre-test was to identify the students' performance in the specific features that were under study in this project before the interventions. The pre-test consisted of writing a 300-400-word expository essay based on the topics students had covered in class. Students wrote the essay at the beginning of the study without previous instruction from the researcher.

\subsubsection{Observation sheets}

The aim of the observations was to evaluate the process and students' accomplishment of CRTs during the interventions. The instruments contained four columns. One column contained the descriptors to be observed (the steps of CRTs' cycle and students' performance while completing the tasks). The other two columns were "yes and no columns" for researchers to check. The last column was used to take notes. Also, each observation sheet was adapted according to the feature under study. This instrument was applied during each of the four interventions by the researchers as well as the cooperating teacher.

\subsubsection{Ongoing assessment sheet}

The objective of the ongoing assessment was to collect data about the students' perceptions of the usefulness of the different tasks after having completed the CRT cycle. The questions varied depending on the feature addressed. This instrument consists of a sheet with three columns. One column listed the indicators to be assessed. The remaining two columns were "yes and no" columns for students to check. Additionally, the instrument contained an open-ended question. Finally, the instrument provided a list of task limitations for students to tick. The assessment was applied to the students after every task cycle was completed.

\subsubsection{Scoring rubric for written assignments}

The aim of the rubric was to assess the students' written assignments in the specific features imposed in the project, pre-test, and post-test. The rubric included six aspects. The 
first column contained the criteria assessed: introduction (hook and background, and thesis statement), body paragraphs (body paragraph 1, body paragraph 2 and body paragraph 3), conclusion, coherence, cohesion, grammar, and mechanics. The other columns contained the different levels of performance. The descriptors in the top row indicated the rating three being the highest score and 0 the lowest score. Researchers implemented the rubric to assess students' written assignments in the pre-test and post-test.

\subsubsection{Post-test}

The purpose was to assess the students' performance in the specific features treated in the project. The post-test also consisted of writing a 300-400-word expository essay based on the topics students had covered in class. Students took the post-test after having completed the interventions.

\subsubsection{Performance-based rubric}

The aim of the rubric was to assess students' performance (elementary, beginner, intermediate or advanced) in the pre-test and post-test. The rubric was divided into four columns. Each of the columns described the level of performance: advanced, intermediate, beginner, and elementary. The levels in the top row indicated the performance rating 76-100 being the highest score and 0-25 the lowest score. Researchers applied the rubric to assess students' performance in the pre-test and post-test. (appendix 1)

\subsubsection{Questionnaire for students' perceptions}

This instrument was used to assess the effectiveness of the tasks from the students' perception. The questionnaire included both open and close-ended questions related to the overall effectiveness of CRTs. The questionnaire was applied to the students after having undergone all the interventions proposed in this project.

\subsubsection{Interview to the cooperating teacher}

This interview was used by the cooperating teacher to provide his/her perception of the effectiveness of CRTs. This instrument had open-ended questions; including eleven open questions and four close questions. The interview was applied to the cooperating teacher once all the interventions had been completed. 


\section{Data Analysis}

The researchers calculated the mean score of the pre-test and post-test to determine the rate of success at the end of the interventions. The analysis had a descriptive purpose and thus, was not intended to focus on significant differences in scores. The information gathered from the observation sheets, post-intervention assessment, students' questionnaire, and the cooperating teacher's interview were triangulated with the perspective of the students, the cooperating teacher, and the researchers in regard to the effectiveness of CRTs.

\section{Results}

In this section, the results of students' performance in essay writing are presented, focusing on their improvement in cohesion, text structure, and coherence. Next, the perceptions of the students and the cooperating teacher and the point of view of the researchers are described with the aim of analyzing the applicability of CRTs to writing.

\subsection{Results of CRTs focused on the writing features under study}

The purpose of this assessment was to compare the students' results before and after the interventions to measure their overall improvement by the end of the interventions. To grade this assignment, a scale was created by the researchers. It ranged from 0 to 100 , divided into the levels advanced (76-100), intermediate (51-75), beginner (26-50) and elementary (0-25). The following graph shows the students' level of performance results. 
Figure 3

Palmares Bilingual High School, Costa Rica: Average results per level of performance according to test, 2018.

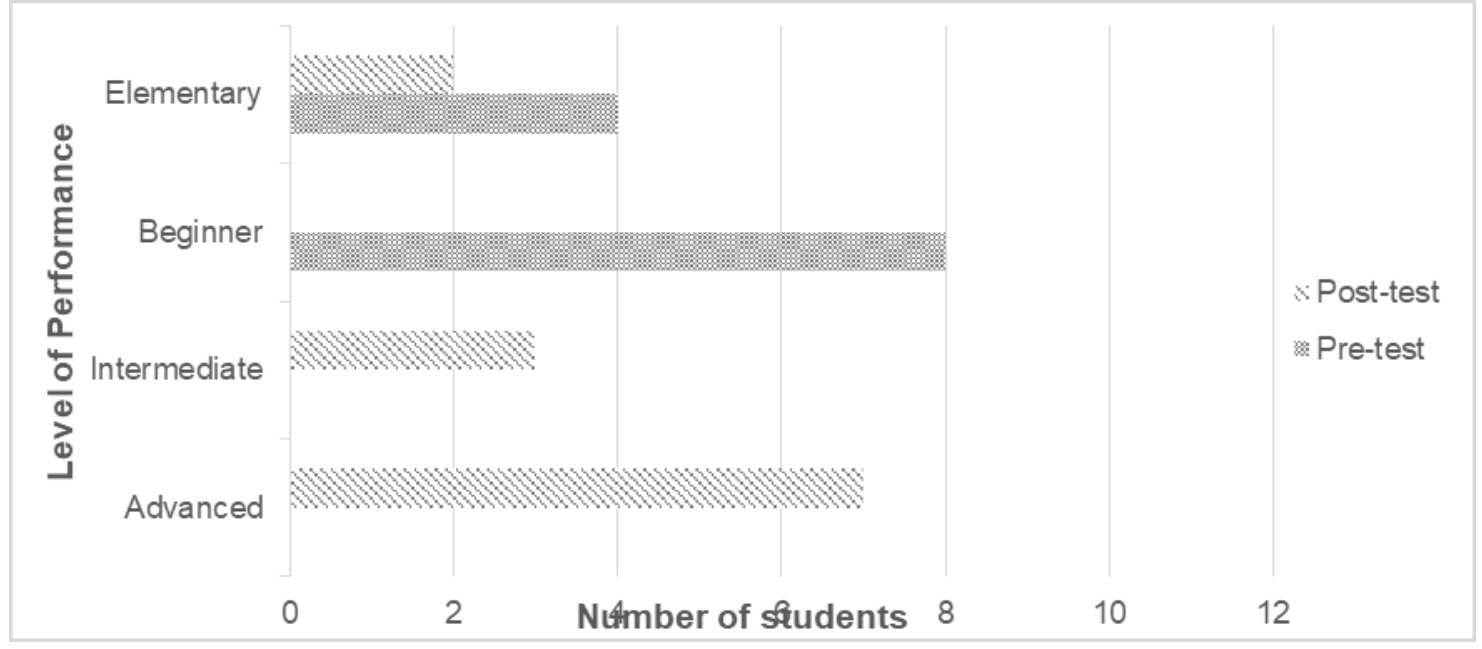

Source: Researchers' calculation based on the results from the pre-test, July 2018, and post-test, August 2018.

In order to identify the different levels of students' performance, the researchers used the grades from the pre-test and post-test and organized them from the highest score to the lowest score. Then, researchers classified students' grades into their corresponding level. In the pretest, the majority of the students were allocated in the beginner level. In this level, the introduction lacked either a hook or background information, and the thesis statement was vague. Then, one or two of these elements were missing, and the ones present were not fully developed, the thematic unity of the entire essay was broken in two paragraphs or in three or more supporting ideas. In the beginner level, cohesion was somewhat compromised and the connection of ideas was unclear.

The level of students' performance in the post-test yielded better results. The majority of students were placed in the advanced level. In this case, the students were able to write an introduction with an interesting hook, sufficient background information, and a well-developed thesis statement. Also, each of the paragraphs contained the four elements fully or mostly developed. The ideas in each paragraph were clearly linked to the topic sentence. The essays' thematic unity improved considerably. The conclusion contained a summary of the key points in the essay, and the transitions were applied correctly. In general, most of the students demonstrated consistent standard English usage.

The degree of improvement in essay scores could be related to a positive effect of the steps in the CRT cycle. Based on Widodo's observation (2006), both the deductive and 
inductive methods have a significant value for teaching. According to the author, students can learn deductively and inductively, depending on their cognitive style, prompted by the step cycle. The immediate feedback and the explanations provided by the researchers were key factors in the improvement of the students' performance. However, there were a few students who had limited improvement probably because of their language proficiency and unexpected obstacles in the administration of the tasks, such as class interruptions, time pressure, low interest in the class, or perceived difficulty of the tasks.

A more detailed analysis of the features in the essays was conducted using data from the pre-test and the post-test. Figure 4 shows the results in text structure, cohesion, and coherence.

Figure 4

Palmares Bilingual High School, Costa Rica: Average score per feature under study according to test, 2018

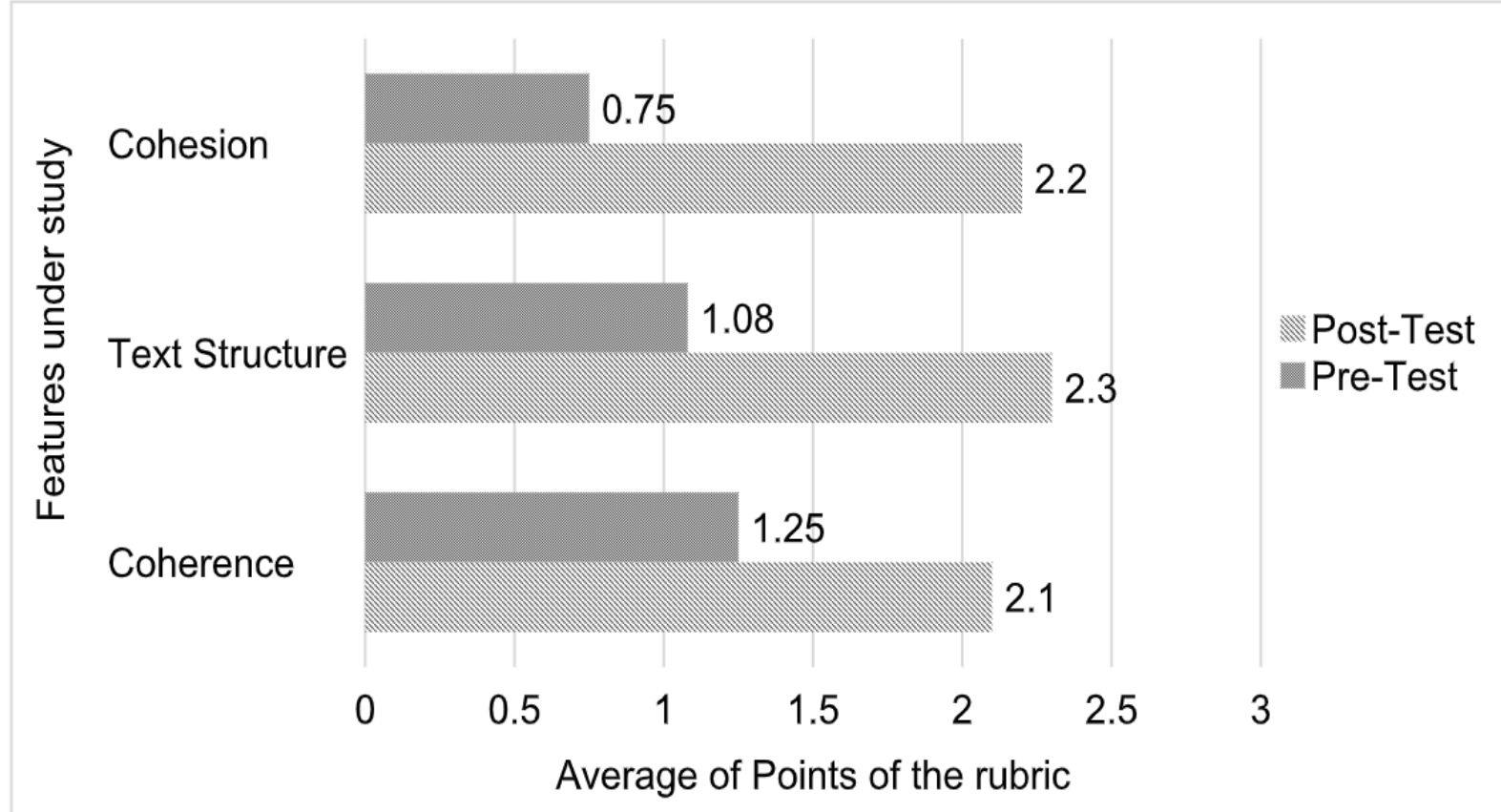

Source: Researchers' calculation based on the results from the pre-test, July 2018, and post-test, August 2018.

When both results are compared in a descriptive manner, the feature in which students improved the most was cohesion. Students had an average improvement of 1.45 points, which means almost double. One of the main possible reasons for the last result may have been the teachers' constant reminder of the explanation of the features, examples, and rules. According to Cross (2002), when the instruction of a language feature is frequently repeated, students may have more opportunities for noticing. This strategy was applied through the 
instruction of the researchers in the form of constantly asking questions about the features, which allowed students to gradually discover patterns of language and incorporate them into their written production.

\subsection{Students' perception of the impact of CRTs}

At the end of the interventions, the students were given a questionnaire where they indicated if the factors listed in Table 1 impacted positively or negatively their performance while working on the tasks.

\section{Table 1}

Palmares Bilingual High School, Costa Rica: Students' perception of the effect of factors on their performance, 2018

\begin{tabular}{lll}
\hline Factor & Positive & Negative \\
\hline 1. The topic of the readings & 12 & 0 \\
2. Text with bolded examples & 12 & 0 \\
3. Questions to analyze the text & 11 & 1 \\
4. Instructions in the exercises & 11 & 1 \\
5. Explanations & 11 & 1 \\
6. Feedback & 12 & 0 \\
7. Group work & 8 & 4 \\
8. Time for exercise completion & 6 & 6 \\
9. The English level of the text & 12 & 0 \\
10. Vocabulary in the exercises & 12 & 0 \\
11. The sequence of the exercises & 12 & 0 \\
12. Interruptions during class time & 2 & 10
\end{tabular}

Source: Researchers' calculation based on the results of the final questionnaire for the students, August 2018.

The students agreed that the following factors involved in the interventions had a positive impact on their task performance: the topic of the readings, text with bolded words, feedback, the English level of the text, and the vocabulary in the sequence of exercises. As for the negative factors, the highest rated were limited available time for exercise completion and interruptions during class time. This can be explained because during the interventions, there were several interruptions from students and professors not involved in the group. This may have interfered with the process of students paying attention to the researchers' explanations. 


\subsection{Cooperating teacher's perception of tasks}

The cooperating teacher was in charge of observing the application of CRTs with the goal of perceiving students' improvement, degree of understanding, and accomplishment of the tasks during the interventions. Additionally, the cooperating teacher was interviewed with the purpose of providing her perception of the effectiveness and possible limitations of CRTs. This last step took place after the interventions were completed.

According to the cooperating teacher's opinion, the complexity of the exercises, the sentences' structure, the vocabulary taught, and the examples provided were appropriate for the students' English level. In addition, available time was a factor that influenced the development of the production steps in the text structure and cohesion features. Based on the cooperating teacher's interview, in the independent exercises, time was a factor that did not allow students to finish the exercises and, as a consequence, they were under pressure. In her words, the students should have had more time for the correct completion of the independent exercises. For the other sections of the tasks, she felt that time was sufficient.

In general terms, the cooperating teacher perceived all the interventions as complete and well organized. The teacher's perception focused on the organization of the interventions, development of the class, researchers' explanation, materials, and the improvement of the students regarding the feature studied. As for the organization of the interventions, the cooperating teacher mentioned that they followed all the steps easily and with appropriate explanations according to the students' English level. Also, she considered the materials contained enough examples and clear explanations.

Asked for the features studied, the cooperating teacher observed an improvement in text structure in general, but specifically in an example where the students were provided with a thesis statement and they had to write topic sentences and supporting ideas for it. In that example, the students could write and organize a draft according to the instructions given without asking for help. In respect to cohesion, the students were aware of the explanation process and of the rules of the feature. The cooperating teacher noticed it when the researchers asked the students about the rules and usage of the writing features and the students were able to explain and apply them when writing. When the cooperating teacher referred to coherence, she believed that the students understood the explanation of the feature; however, when they tried to put the knowledge gained into practice, most learners were not able to connect ideas from sentence to sentence or larger blocks of texts within a coherent paragraph. 


\subsection{Researchers' perception of the usefulness of CRTs}

The researchers observed an improvement in the following areas of text structure: thesis statement, topic sentences, and closing devices. Initially, problems had been observed in formulating thesis statements, in coherence between the thesis statement and the topic sentences, and in the production of closing devices. At the end of the process, a few students still had difficulties formulating thesis statements, which was fundamental for the introduction.

In regard to cohesion, the researchers perceived that some students went beyond the explanations provided by the teacher and came up with more possible ways of using the feature explained in the previous intervention, which was text structure. The majority of the students wanted to use different connectors in their pieces of writing, and they even wanted to mix them, so they often asked their teacher whether or not they could use two connecting words together. The researchers corroborated that the students understood the usage of each one and that the exercises prompted them to come to such outcomes on their own.

As for coherence, the researchers observed that the students seemed to have understood the rules of the feature and tried to apply them in their writing. Although the students applied what they learned about the feature, notably with the use of conjunctions and subordinators, their capacity to achieve coherence between larger blocks of text was still limited. For example, they came up with new supporting sentences for their paragraphs that did not always have a clear connection to the topic sentences. This points to the complexity of integrating reading and writing skills to improve coherence.

Lastly, the researchers noticed that peer-assessment contributed to improving the level of students. As a result of the peer evaluation process, two students highlighted the need to focus on the difference between a concluding sentence to close a paragraph and a conclusion to close the essay because they became confused in distinguishing both terms among their classmates. This suggests that collaborative work can be conducive to consciousness- raising, and in turn, to a better understanding of metalanguage.

\section{Discussion}

In the following section, the students', the cooperating teacher's, and the researchers' perceptions were triangulated. The perspectives were analyzed in the light of the theories of the Noticing Hypothesis and CR to evaluate the effectiveness of the tasks for mediating text structure, cohesion, and coherence in International Baccalaureate English classes. The 
triangulation was based on the improvement of the features and the perception of the usefulness of CRTs.

As can be observed in the previous section, the students had the greatest improvement in the cohesion and text structure. This was reflected in the way essays were structured and the use of transitional expressions in different sections of the text. The cooperating teacher's results also suggested that the majority of the students gradually improved in these areas, especially in the editing section. The researchers concluded that most of the students noticed the features during the interventions and were able to put them into practice through the series of exercises provided in each task cycle. Although all the students did not improve their level of performance, the majority of them had positive results, mainly due to the explanations and examples given in context. As stated in the theory of CR discussed in previous sections, Ellis (2002) claimed that "the purpose of CRTs is not to enable learners to perform a structure correctly, but to help them realize its existence" (p.169). Ellis' stance was reflected in this study because the students were able to notice the existence of the features.

In regard to coherence, it was perceived by the cooperating teacher and the researchers, as the least improved feature, which was reflected in the results obtained. Coherence may have been more challenging to fully achieve because it required students to incorporate all the writing rules acquired when covering the previous features. As stated in the literature review, editing for coherence means to fit all the ideas in a logical order, establishing a clear relation between words, sentences, and paragraphs; this may help the text achieve an appropriate flow. This points to coherence being a cumulative skill that takes more time to develop and implies a higher complexity when revising a text. Language proficiency is undoubtedly an indicator of this skill. Even when students improved in the post-test, the results were only performance-based and language proficiency takes more time to develop.

Overall, it was observed that the students did not struggle in applying the rules of cohesion and text structure as a result of the easy-to-follow patterns that were provided and explained. Conversely, coherence was more challenging for the students because they could not follow specific rules or patterns that they could take as a step-by-step manual.

As for factors related to the tasks, the cooperating teacher claimed that the guided questions helped the students focus their attention on specific points, which led to successful identification of the feature for most of the students. Similarly, the students perceived the guided questions as a way of easily identifying the text structure, cohesion, and coherence in the essay. Furthermore, the researchers concluded that following Swales and Feak, and 
Widodo's CR theories, the students were provided with comprehensible input to give them the opportunity to notice each of the elements asked in the questions.

The students were satisfied with the explanation of the features because questions were answered effectively and more examples were provided when necessary. In the same way, the cooperating teacher and the researchers stated that the explanations were clear and helped those students who have more difficulty understanding rules implicitly. Even though the students perceived the exercises as relatively easy, not all the answers incorporated each of the features correctly. The cooperating teacher mentioned that students put into practice the input provided in the researchers' explanation. She also stated that open exercises were challenging for students because they had to apply the feature using their own ideas. In addition, the researchers agreed that the most difficult steps were the independent exercises, in which students had to write sentences and paragraphs using the feature. This leads to the need for incorporating more input-based activities to prepare students for successfully producing a text.

Lastly, while students identified and corrected mistakes in context, noticing strategies helped them remain focused on the step. The students considered this step as one of the easiest to complete although not all of them corrected the mistakes as expected. According to the cooperating teacher, the students acquired most of the concepts explained to identify and correct the last step satisfactorily. This shows that identification and correction of mistakes are separate skills even though one builds upon the other. This points to cases where there may be gaps in knowledge. It is expected that students should be able to acquire both skills with additional practice and reflection guided by the instructor and through the tasks.

\section{Conclusions}

This study has been primarily concerned with assessing the effectiveness of CRTs for the mediation of text structure, cohesion, and coherence as a way of determining their possible applicability at Palmares Bilingual High school. After having applied the interventions and observing the results, CRTs have yielded positive results, meaning that the students developed a gradual awareness and understanding of the features in essay writing. This study and its results motivate to develop similar or larger applications within populations with comparable characteristics as the findings cannot be generalized to other populations based on the conditions of the project. 
The results proved that the preliminary application of an instrument for determining the students' level of performance before the interventions was a fundamental key for correctly tailoring the materials to the appropriate English level. In this instrument, the majority of the students were classified in the beginner level. After applying CRTs, the results showed that the majority of the students were placed in the advanced level, this might confirm the first positive result presented in the project.

As for the results obtained in the interventions, CRTs appear to foster a conscious analysis of the feature in question. Students focused on understanding different patterns, rules, examples, and compared and analyzed every detail together. Students were able to focus on these aspects by following the steps proposed by Widodo. Also, the patterns and examples given to the students helped them to notice particular features. The methodology of CRTs consisted of an inductive method complemented with a deductive method. In the inductive method, students noticed the rule, or feature while in the deductive method the rule was taught explicitly. These methods help those students that are not able to understand the rule inductively but challenge those students who want to notice the rules, be aware of their mistakes, and find a way to correct them.

Based on the results from the pre-test and post-test, there was an improvement in the final results. The feature with the highest improvement was cohesion with almost double the score in comparison to the pre-test, then text structure, and the lowest improvement was in coherence. It was identified that the greatest improvement in the features of cohesion and text structure might have been obtained because students followed patterns, specific rules, and short pieces of exercises. However, it can be argued that coherence as the feature with the lowest improvement needs more practice. Coherence takes more time to be developed correctly; students need to achieve a conscious understanding of the unity of the essay from top to bottom. Furthermore, students have to pay attention to the connection from sentence to sentence and from paragraph to paragraph.

As observed in the students' perceptions of CRTs, they agreed on some factors that caused a positive effect on task performance. The factors were the topic of the readings, texts with bolded words, feedback, the English level of the text, and the sequence of the exercises. In addition, peer-feedback is a technique that can be exploited even further with CRTs. As can be seen, the students can notice their mistakes sooner by comparing their work against that of their peers. On the other hand, negative factors in the study were time for completion 
of the exercises and interruptions during the class. This can be analyzed in future research taking into account the sessions and the time allotted for each intervention.

Lastly, another important finding showed that students made an improvement in aspects such as grammar and punctuation even though these were not the target features. The fact that students had the highest improvement in cohesion can be linked to their improvement in sentence structure and punctuation in the post-test due to a clear understanding of the cohesive devices and their corresponding punctuation.

For future research, the authors recommend examining the benefits of CRTs in groups with different levels of proficiency over a longer period of time. In addition, the authors suggest enquiring about the impact of these tasks on relatively simple topics with clear rules such as cohesion vs. more complex topics involving abstract thinking and decisions not always linked to rules, like coherence. Finally, the authors recommend exploring strategies to make consciousness-raising a collaborative process.

\section{References}

Barrantes, Dayan., Madrigal, Diego., Quesada, Estefany., Salazar, Jean Pool., Rojas, Massiel. and Vargas, José Miguel. (2018). Consciousness-Raising Tasks for the Learning of Grammar in High School English Language Classroom. (Licenciatura thesis) Universidad de Costa Rica, Alajuela, San Ramón, Costa Rica.

Brizee, Allen. and Driscoll, Danna. (2015). On Paragraphs. Purdue Online Writing Lab. Retrieved from https://owl.english.purdue.edu/owl/resource/606/01/

Cox, Beverly., Shanahan, Timothy., and Sulzby, Elizabeth. (1990). Good and poor elementary readers' use of cohesion in writing. Reading Research Quarterly, 25(1), 4765. doi: $10.2307 / 747987$.

Creswell, John. (2014). Research design: qualitative, quantitative, and mixed methods approaches. Thousand Oaks, California: SAGE Publications.

Cross, Jeremy. (2002). 'Noticing' in SLA: Is it a valid concept? TESL-EJ, 6(3), 1-12.

Crossley, Scott., and McNamara, Danielle. (2010). Cohesion, coherence, and expert evaluations of writing proficiency. Proceedings of the Annual Meeting of the Cognitive Science Society, 32, 984-989. Retrieved from https://escholarship.org/uc/item/6n5908qx.

Ellis, Rod. (1990). Instructed Second Language Acquisition. Oxford: Blackwell Publishers Ltd.

Ellis, Rod. (1994). The Study of Second Language Acquisition. Oxford: Oxford University Press. 
Ellis, Rod. (1997). SLA Research and Language Teaching. Oxford: Oxford University Press.

Ellis, Rod. (2002). Grammar Teaching - Practice or Consciousness-Raising? In J. Richards \& W. Renandya (Eds.), Methodology in language teaching: An anthology of current practice (Approaches and Methods in Language Teaching, pp. 167-174). Cambridge: Cambridge University Press. doi: 10.1017/CBO9780511667190.023

Ferris, Danna. (2014). Language Power. Tutorials for Writing. University of California: Bedford/St. Martin's.

Fotos, Sandra. and Ellis, Rod. (1991). Communicating about Grammar: A Task-based Approach. TESOL Quarterly, 25(4), 605-628. doi: 10.2307/3587079

Gass, Susan. (1988). Integrating research areas: a framework for second language studies. Applied Linguistics, 9(2), 198-217. doi: https://doi.org/10.1093/applin/9.2.198

Gass, Susan. and Selinker, Larry. (2013). Second Language Acquisition: An introductory Course. New York: Routledge Source.

Krashen, Stephen. (1982). Principles and practice in second language acquisition. Oxford: Pergamon Press.

Mettetal, Gwynn. (2002). The what, why and how of classroom action research. Journal of the Scholarship of Teaching and Learning, 2(1), 6-13. Retrieved from https://scholarworks.iu.edu/journals/index.php/josot//article/view/1589

Nugraheni, Ratnasari. (2016). Cohesive Devices in Learners' Writing. LLT Journal: A Journal on Language and Language Teaching, 18(1), 51-62. doi: https://ejournal.usd.ac.id/index.php/LLT/article/view/257

Perutz, Vivien. (2010). A Helpful Guide to Essay Writing! Cambridge and Chelmsford: Student Services. Retrieved from https://web.anglia.ac.uk/anet/students/documents/2010/helpful-guide-to-essaywriting.pdf

Roza, Veni. (2014). A model of grammar teaching through consciousness-raising activities. International Journal on Studies in English Language and Literature (IJSELL), 2(3), 1-5.

Rutherford, William. (1987). Second language grammar: Learning and teaching. London: Longman.

Rutherford, William., and Sharwood, Michael. (1985). Consciousness-raising and universal grammar. Applied Linguistics 6(3), 274-82. doi: https://doi.org/10.1093/applin/6.3.274

Schmidt, Richard. (1990). The role of consciousness-raising in second language learning. Applied Linguistics 11(2), 129-158 . doi: https://doi.org/10.1093/applin/11.2.129 
Schmidt, Richard. (1995). Consciousness and foreign language learning: A tutorial on the role of attention and awareness. In R. Schmidt (Ed.), Attention and awareness in foreign language teaching and learning. Honolulu: University of Hawaii Press.

Swales, John. and Feak, Christine. (2009). Abstracts and the Writing of Abstracts. Michigan: University of Michigan Press ELT.

Truscott, John. (1998). Noticing in second language acquisition: A critical review. Second Language Research, 14(2), 103-135.

Tomlin, Russell. and Villa, Victor. (1994). Attention in Cognitive Science and Second Language Acquisition. Studies in Second Language Acquisition, 16(2), 183-203. doi: https://doi.org/10.1017/S0272263100012870

Widodo, Handoyo. (2006). Approaches and procedures for teaching grammar. English Teaching: Practice and Critique, 5(1), 122-141

Zemach, Dorothy E. and Rumisek, Lisa. (2003). Academic Writing from paragraph to essay: Oxford: Macmillan.

Zemach, Dorothy., and Stafford-Yilmaz, Lynn. (2008). Writers at Work: The Essay. New York: Cambridge, University Press. 


\section{Appendix 1}

\section{Performance-Based Rubric}

Objective of the rubric: the aim of the rubric is to assess the students' performance in an essay writing.

\begin{tabular}{|c|c|c|c|}
\hline $\begin{array}{c}76-100 \\
\text { ADVANCED }\end{array}$ & $\begin{array}{l}51-75 \\
\text { INTERMEDIATE }\end{array}$ & $\begin{array}{c}26-50 \\
\text { BEGINNER }\end{array}$ & $\begin{array}{c}0-25 \\
\text { ELEMENTARY }\end{array}$ \\
\hline $\begin{array}{l}\text { According to the } \\
\text { advanced level, the } \\
\text { student is able to write } \\
\text { an introduction with an } \\
\text { interesting hook and } \\
\text { sufficient background } \\
\text { information. The } \\
\text { student is able to } \\
\text { include a well- } \\
\text { developed thesis } \\
\text { statement (author's } \\
\text { point of view + three } \\
\text { clearly distinct } \\
\text { controlling ideas). } \\
\text { Concerning the body } \\
\text { paragraphs, each of } \\
\text { them contains the four } \\
\text { elements fully } \\
\text { developed. (Effective } \\
\text { topic sentences, } \\
\text { supporting ideas, } \\
\text { evidence and a } \\
\text { concluding sentence). } \\
\text { The ideas in each } \\
\text { paragraph are clearly } \\
\text { linked to the topic } \\
\text { sentence. The thematic } \\
\text { unity of the entire essay } \\
\text { is unquestionable. The } \\
\text { conclusion contains a } \\
\text { summary of the key } \\
\text { points in the essay and } \\
\text { an effective closing } \\
\text { device related to the } \\
\text { thesis statement. The } \\
\text { student is able to use } \\
\text { transitions correctly to } \\
\text { mark relationships of } \\
\text { addition, contrast, } \\
\text { exemplification or } \\
\text { cause and effect } \\
\text { between ideas. The }\end{array}$ & $\begin{array}{l}\text { According to the } \\
\text { intermediate level, the } \\
\text { student is able to write } \\
\text { an introduction with a } \\
\text { hook, and some } \\
\text { background } \\
\text { information. The } \\
\text { student is able to } \\
\text { include a general thesis } \\
\text { statement (author's } \\
\text { point of view + three } \\
\text { broad or overlapping } \\
\text { ideas). Concerning the } \\
\text { body paragraphs, the } \\
\text { body paragraph is } \\
\text { missing only one } \\
\text { element; the elements } \\
\text { present are fully } \\
\text { developed. Most of the } \\
\text { ideas in each } \\
\text { paragraph are clearly } \\
\text { linked to the topic } \\
\text { sentence. The thematic } \\
\text { unity of the entire essay } \\
\text { is broken in one } \\
\text { paragraph or in two } \\
\text { supporting ideas. The } \\
\text { conclusion contains a } \\
\text { summary of the key } \\
\text { points in the essay and } \\
\text { a closing device not } \\
\text { clearly related to the } \\
\text { thesis statement. The } \\
\text { student has two to } \\
\text { three mistakes in the } \\
\text { use of transitions and } \\
\text { three to five errors in } \\
\text { the following areas: } \\
\text { agreement, verb tense, } \\
\text { word order, articles, } \\
\text { pronouns, or } \\
\text { prepositions. }\end{array}$ & $\begin{array}{l}\text { According to the } \\
\text { beginner level, the } \\
\text { introduction lacks either } \\
\text { a hook or background } \\
\text { information, and the } \\
\text { thesis statement is } \\
\text { vague (author's point of } \\
\text { view + two or one } \\
\text { vague controlling } \\
\text { ideas). Concerning the } \\
\text { body paragraphs one or } \\
\text { two elements are } \\
\text { missed, the elements } \\
\text { present are not fully } \\
\text { developed. Two topic } \\
\text { sentences are not } \\
\text { related to the points in } \\
\text { the thesis statement. } \\
\text { Only one idea is linked } \\
\text { to the topic sentence. } \\
\text { The thematic unity of } \\
\text { the entire essay is } \\
\text { broken in two } \\
\text { paragraphs or in three } \\
\text { or more supporting } \\
\text { ideas. The conclusion } \\
\text { summarizes only some } \\
\text { of the key points in the } \\
\text { essay and the } \\
\text { concluding device is } \\
\text { missing or ineffective. } \\
\text { The essay contains four } \\
\text { to five mistakes in use } \\
\text { of transitions. Cohesion } \\
\text { is somewhat } \\
\text { compromised. The } \\
\text { student has between } \\
\text { six and seven errors in } \\
\text { the following areas verb } \\
\text { tense, word order, } \\
\text { articles, pronouns, or } \\
\text { prepositions. The }\end{array}$ & $\begin{array}{l}\text { According to the } \\
\text { elementary level, the } \\
\text { introduction lacks the } \\
\text { hook and background } \\
\text { information, and the } \\
\text { thesis statement } \\
\text { consists solely of one } \\
\text { idea. Concerning the } \\
\text { body paragraphs more } \\
\text { than two elements are } \\
\text { missed, and the } \\
\text { elements present are } \\
\text { not fully developed. The } \\
\text { thematic unity is barely } \\
\text { recognizable. The } \\
\text { conclusion fails to } \\
\text { summarize any of the } \\
\text { key points and the } \\
\text { concluding device is } \\
\text { missing or ineffective. } \\
\text { The student has more } \\
\text { than five mistakes in } \\
\text { the use of transitions. } \\
\text { Cohesion is severely } \\
\text { affected. More than } \\
\text { seven errors in the } \\
\text { following areas: } \\
\text { agreement, verb tense, } \\
\text { word order, articles, } \\
\text { pronouns, or } \\
\text { prepositions and more } \\
\text { than seven errors in } \\
\text { usage, } \\
\text { capitalization spelling, } \\
\text { punctuation. Meaning is } \\
\text { often unclear }\end{array}$ \\
\hline
\end{tabular}




\begin{tabular}{|c|c|c|}
\hline $\begin{array}{l}\text { student has less than } \\
\text { two errors in the } \\
\text { following areas: } \\
\text { agreement, verb tense, } \\
\text { word order, articles, } \\
\text { pronouns, } \\
\text { prepositions. } \\
\text { general, the student } \\
\text { uses } \\
\text { standard consistent } \\
\text { usage, and the student } \\
\text { has } \\
\text { capitalization spelling, } \\
\text { punctuation and }\end{array}$ & $\begin{array}{l}\text { student has between } \\
\text { three and five errors, } \\
\text { but none major in } \\
\text { usage, spelling, } \\
\text { capitalization } \\
\text { punctuation, or } \\
\text { meaning is mostly } \\
\text { clear. }\end{array}$ & $\begin{array}{l}\text { student has between } \\
\text { six and seven errors in } \\
\text { usage, spelling, } \\
\text { capitalization or } \\
\text { punctuation. Meaning is } \\
\text { unclear at times. }\end{array}$ \\
\hline
\end{tabular}


Revista indizada en

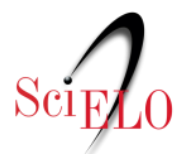

redalyc satindex

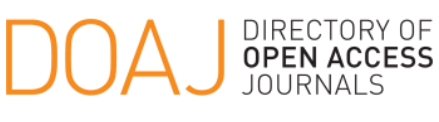

Distribuida en las bases de datos:

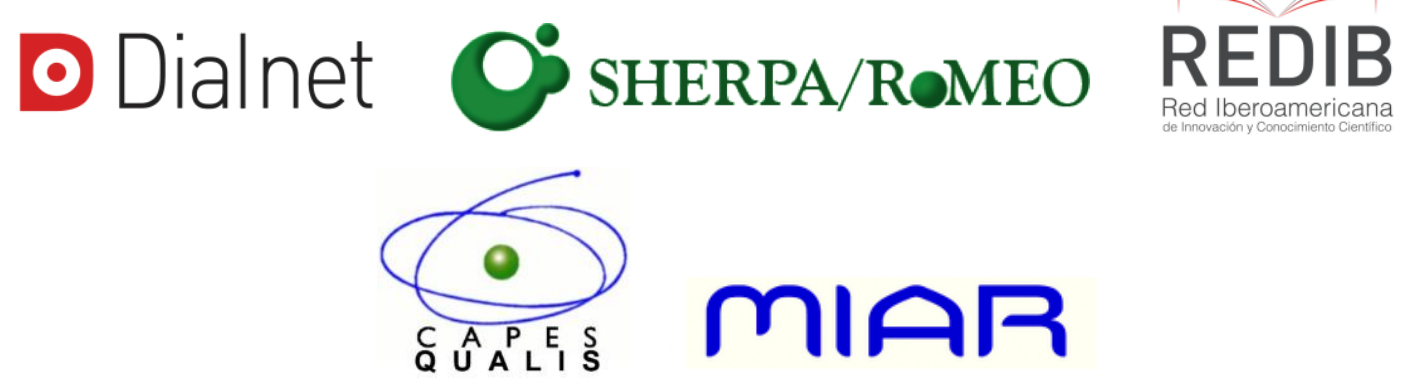

